Удк $611.132-019$

DOI: $10.24061 / 1727-0847.16 .1 .2017 .21$

\title{
М.Н. Цитовський
}

Львівський начіональний медичний університет імені Данила Галищького

\section{ПОРІВНЯЛЬНА АНАТОМІЯ АОРТИ ТА ЇЇ ГІЛОК}

Резюме. Стаття присвячена дослідженню порівняльної макроанатомії аорти білого щура. У роботі наведені відомості щодо організації відділів аорти, розгалуження ії основних гілок. Отримані результати дослідження можуть бути корисними при моделюванні захворювань аорти, оскільки необхідно враховувати особливості макроструктури аорти експериментальної тварини для екстраполювання експериментальних даних в медичну практику.

Ключові слова: анатомія аорти, білий щур.

Ураження судин належить до тяжких патологій, які трапляються в щоденній лікарській практиці (патологія судин при атеросклерозі, інфекційні захворювання, вроджені аномалії, травми, цукровий діабет тощо), що доволі часто призводять до безпосередньої небезпеки для життя хворого. Діагностика та лікування судинної патології потребують досконалих знань анатомії судин в нормі. Порушення кровотоку в аорті та їі основних гілках супроводжується тяжкими та широко розповсюдженими захворюваннями: гострими порушеннями мозкового та серцевого кровообігу, артеріальною гіпертензією при ураженні ниркових артерій, наднирковою недостатністю при їх неадекватному кровопостачанні, тромбозами мезентеріальних судин і т. д. Патологія судин таза призводить до захворювань органів сечостатевої системи, частини травного тракту, нижніх кінцівок. Наслідками несвоєчасної діагностики та лікування цих захворювань $\epsilon$ втрата працездатності пацієнтів. Незважаючи на наявність численних праць, присвячених вивченню анатомії аорти білого щура та людини на макрорівні в нормі, peзультати нашого дослідження дадуть змогу систематизувати та доповнити існуючу наукову інформацію, яка стосується анатомії аорти та її гілок у експериментальних тварин. Робота $€$ фрагментом науково-дослідної роботи Львівського національного медичного університету імені Данила Галицького "Морфологічні особливості гемомікроциркуляторного русла стінки аорти щура в нормі та при експериментальному цукровому діабеті".

Мета дослідження: З'ясувати особливості анатомії відділів аорти та розгалуження іiї на основні групи гілок у білого щура на макрорівні.

матеріал і методи. Під час виконання ро- боти використано такі методи дослідження: препарування, фотографування.

Експеримент проводили на 10 статевозрілих щурах-самиях лініі "Вістар” масою 150-180 г, віком 4,5-7,5 міс. Усі тварини перебували в умовах віварію відповідно "Правил проведення робіт 3 використанням експериментальних тварин”. Евтаназію проводили методом передозування внутрішньоочеревинного наркозу з використанням тіопенталу (з розрахунку $25 \mathrm{mz} / к 2$ ).

Результати дослідження та їх обговорення. При вивченні макроанатомії аорти щура нами визначені типові, як і для людини [1-5], відділи: висхідний відділ аорти, дуга аорти та низхідний відділ аорти, з відповідним розгалуженням на основні гілки. Висхідний відділ аорти - це початкова частина аорти, яка виходить 3 лівого шлуночка, прямує догори і дещо дозаду та розташована в товщі перикарда. Від висхідного відділу аорти щура беруть початок лише дві гілки - права та ліва вінцеві артерії, що підтверджується даними фахової літератури [6]. Дуга аорти є зігнутою ділянкою судини між висхідною та низхідною аортою, яка перетинається з трахеєю спереду, після чого повертає назад і вниз до лівої стінки трахеї і далі продовжується в низхідний відділ. Від дуги аорти відходять справа - плечоголовний стовбур, зліва ліва загальна сонна та ліва підключична артерії (рис. 1).

Плечоголовний стовбур - це велика судина, що відходить від дуги аорти у верхньо-задньому напрямку, відхиляється вправо і на рівні груднино-ключичного з'єднання розгалужується на праву загальну сонну та праву підключичну артеpiї. Анатомія правої та лівої загальних сонних артерій у білого щура подібна до людської $[7,8]$.

(C) Цитовський М.Н., 2017 


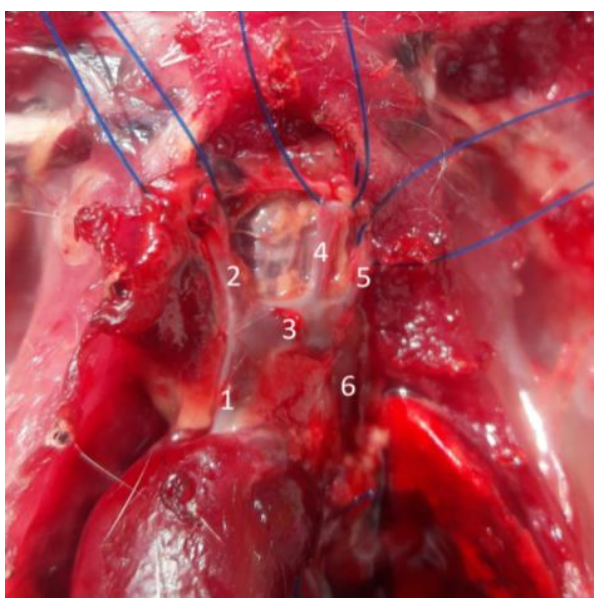

Рис. 1. Аорта щура. Макрофотографія. 1 - висхідна аорта; 2 - плечоголовний стовбур; 3 - дуга аорти; 4 - ліва загальна сонна артерія; 5 -ліва підключична артерія;. 6-низхідна аорта

Права загальна сонна артерія є безпосереднім продовженням плечоголовного стовбура, ліва бере початок самостійно від дуги аорти. Обидві артерії проходять через передню апертуру грудної порожнини, прямують вперед й паралельно до трахеї до рівня розташування щитоподібної залози, де відбувається їх поділ на зовнішню та внутрішню сонні артерії.

Зовнішня сонна артерія є прямим продовженням загальної сонної артерії, яка бере початок на рівні щитоподібної залози, має висхідний напрямок і за своїм ходом розгалужується на п'ять гілок: потиличну артерію, верхню щитоподібну, висхідну глоткову, язикову та висхідну піднебінну артерії. Досягнувши краю щелепи, повертає під прямим кутом назад, проходить невелику відстань і нижче вуха віддає ще чотири гілки: аналог лицевої артерії людини - зовнішню верхньощелепну артерію $[6,8]$, задню вушну артерію, жувальну та передню вушну артерії, яка у щура, на відміну від людини $[1,9], \epsilon$ гілкою поверхневої скроневої артерії, відходить безпосередньо від зовнішньої сонної артерії в ділянці між скроневонижньощелепним суглобом та зовнішнім слуховим ходом. Далі зовнішня сонна артерія знову повертає під прямим кутом і поділяється на свої кінцеві гілки: поверхневу скроневу та на верхню верхньощелепну артерії.

Внутрішня сонна артерія бере початок на рівні нижнього краю щитоподібної залози, прямує вгору і паралельно зовнішній сонній артерії, але більш глибоко вздовж основи черепа. На рівні барабанного міхурця від неї відгалужується крилопіднебінна артерія, яка відповідає розгалуженню гілок верхньощелепної артерії у людини. У подальшому, досягнувши присередньої поверхні міху- рця, внутрішня сонна артерія входить в сонний канал.

Для вивчення судин заднього середостіння легені відводили вперед і розсікали пристінкову плевру справа та зліва вздовж бічних поверхонь тіл хребців. При препаруванні низхідного відділу аорти доведено, що вона, так само як і низхідний відділ аорти людини $[5,7]$, є безпосереднім продовженням дуги аорти, поділяється на грудний та черевний відділ. Візуалізація грудної аорти через парієтальну плевру була задовільна (рис. 2). Грудна аорта - це внутрішньогрудний відрізок низхідного відділу, що простягається від дуги аорти до аортального розтвору діафрагми. На своєму початку розташована лівіше від хребтового стовпа, але при наближенні до діафрагми набуває серединного положення. У білого щура синтопія аорти подібна до людської $[1,3,6]$. Сдиною відмінністю $\epsilon$ те, що у щура ліва верхня порожниста вена постійно перетинає аорту на шляху до серця, та непарна вена розташована не справа, а зліва від аорти [6]. Гілки низхідного відділу, так само як і у людини [1], поділяються на дві групи: пристінкові та нутрощеві. Нутрощеві гілки грудної аорти до перикарда, стравоходу, бронхів та середостінних лімфатичних вузлів, зазвичай, заміщуються гілками реброво-шийного стовбура з правого боку та осердно-середостінною артерією зліва.

Задні міжреброві артерії препарували разом 3 однойменними венами та нервами у складі судинно-нервового пучка. Вони прямують до міжребрових проміжків і простягаються вздовж борозен ребер. У третини експериментальних тва-

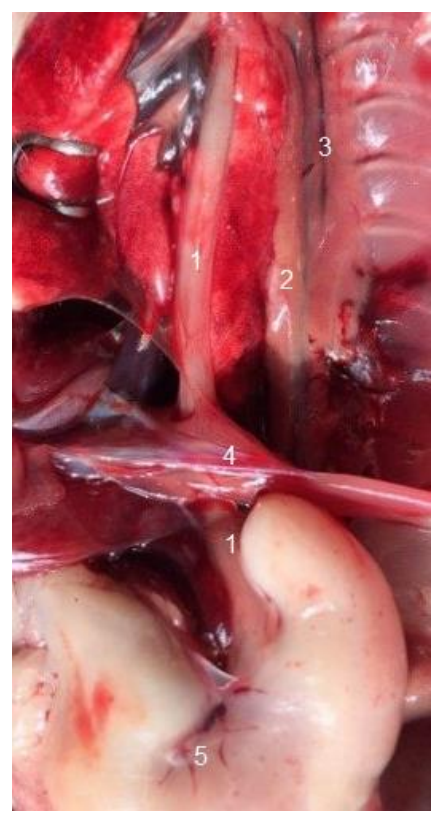

Рис. 2. Аорта щура. Макрофотографія. 1 - стравохід; 2 - грудний відділ аорти; 3 - непарна вена; 4 - дiафрагма; 5 - илунок 
рин з лівого боку, біля довгого м'яза шиї, дві артерії загиналися догори і назад і віддавали одну гілку до спинного мозку, а іншу - до шкіри, глибоких м'язів спини та хребта. За даними літератури, вони, ймовірно, є постійною проксимальною частиною і каудальною гілкою третьої і четвертої міжребрових артерій [6]. М'язові гілки цих артерій до міжребрових м'язів представлені гілками реброво-шийного стовбура. Крім того, у третини тварин виявлено існування тільки нижньої 3 цих двох артерій, а для іншої третини щурів характерна наявність дев'яти пар міжребрових артерій, розташованих сегментарно від IV до XII міжребрових проміжків. Найнижче розташовані дві пари артерій, що прямують назад до квадратного м'яза попереку. Кожна артерія поділяється на передню і задню гілки. Передня гілка - йде косо вгору у напрямку до кута ребра, де вона простягається ззовні в борозні ребра, паралельно до міжребрової вени і нерва. Від кута ребра назовні артерії розта-шовані між зовнішніми і внутрішніми міжребро-вими м'язами. Задня гілка відгалужується близько від початку артерії, спрямована назад, проходить близько до хребця та до шийки ребра і віддає спинномозкову гілку, яка проходить через міжхребцевий отвір до спинного мозку i його оболонок, продовжуючись до шкіри та м'язів спини.

Підреброва артерія утворює XIII пару міжребрових артерій, але оскільки вона розташована нижче XIII ребра, то має назву підребрової артеpiï. Як і нижні міжреброві артерії, вона прикрита біля місця свого відходження квадратним м'язом попереку.

Верхні діафрагмові артерії відходять від нижньої частини грудної аорти, відразу ж входять в діафрагму і кровопостачають ії поперековий відділ.

Подібність в будові з людською $[1,10]$ спостерігається й в черевному відділі аорти білого щура, яка є внутрішньочеревною частиною низхідного відділу аорти. Свій початок бере від аортального розтвору діафрагми і закінчується біфуркацією на праву та ліву загальні клубові артерії (рис. 3). У черевній порожнині вона займає серединне положення, вздовж хребтового стовпа, по серединній лінії дещо позаду нижньої порожнистої вени та перетинається 3 лівою нирковою веною. Кровопостачання стінок черевної порожнини здійснюється низкою пристінкових гілок, до яких належать: нижні діафрагмові, поперекова, клубово-поперекова, серединна хвостова та загальна клубова артерії.

У відгалуженні нижньої діафрагмової артерії

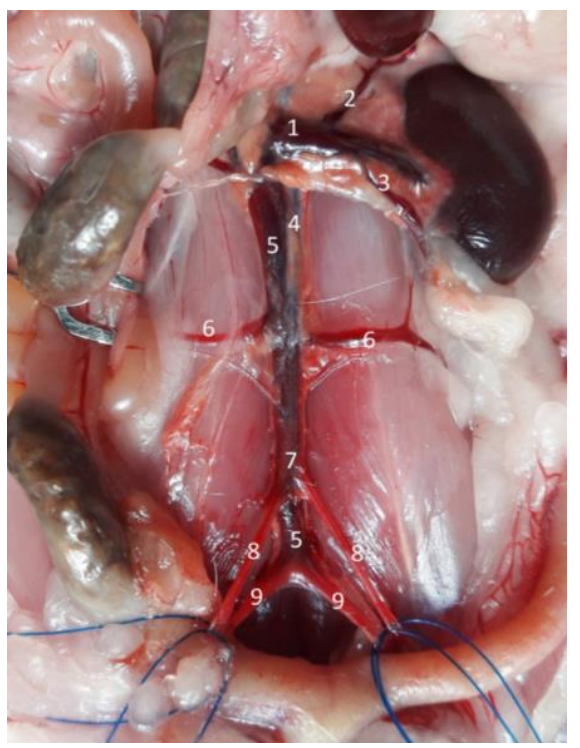

Рис. 3. Аорта щура. Макрофотографія. 1 - ліва ниркова вена; 2 - нижня надниркова вена; 3 -ліва яєчкова вена; 4 - черевний відділ аорти; 5 - нижня порожниста вена; 6 - поперекові вени; 7 - біфуркація аорти; 8- права і ліва загальні клубові артерії; 9 права і ліва загальні клубові вени

спостерігалась асиметричність, що підтверджується літературними даними $[3,6]$. Зліва вона безпосередньо відходила від аорти, справа - від нижньої надниркової артерії. Характерним $є$ те, що обидві артерії перед поворотом догори, до діафрагми, віддають до надниркових залоз верхню надниркову артерію.

Поперекові артерії у кількості п’яти пар судин відгалужуються від черевного відділу аорти. Нижче ніжок діафрагми відходить перша пара артерій, друга пара - на рівні ниркових артерій, третя пара відходить нижче сім'яникової артерії, четверта - нижче правої попереково-клубової артерії, а від серединної хвостової артерії бере початок п’ята пара поперекових артерій. Поперекові артерії візуалізуються ззаду та латеральніше від квадратного м'яза попереку та поперекових м'язів, які вони і живлять. Хід артерій глибокий. 3 правого боку поперекові артерії перетинаються нижньою порожнистою веною.

За даними літератури, відгалуження клубовопоперекових артерій досить варіабельне, що не залежить від статі тварин [6, 11, 12], а саме: права клубово-поперекова артерія відгалужується безпосередньо від черевної аорти, а ліва - від загальної клубової артерії. Ліва клубово-поперекова артерія, на відміну від правої, характеризується меншою стабільністю свого початку. Описані випадки відгалуження на рівні нижнього полюса нирки над правою судиною та нижче сім'яникової артерії, а також від загальної клубової артерії. У 
нашому досліді під час препарування експериментальних тварин спостерігали початок правої клубово-поперекової артерії від черевної аорти, а лівої - від загальної клубової артерії.

Непарна, серединна хвостова артерія, відповідає серединній крижовій артерії у людини [6, 8], продовжуючи хід черевної аорти у хвіст.

Кровопостачання органів черевної порожнини здійснюється вісцеральними гілками черевного відділу аорти. У білого щура ми спостерігали ідентичність поділу, як і в однойменному відділі аорти у людини, на парні та непарні вісцеральні гілки $[2,5,10]$. Отже, до непарних вісцеральних гілок черевної аорти належать: черевна артерія, верхня брижова та нижня брижова артерії, до парних - ниркові і яєчкові артерії. Під час проведення порівняльної анатомії черевної аорти щура та людини відмінність виявилась у тому, що у щура відсутні середні надниркові артерії, які безпосередньо відходять від аорти у людини $[1,9,6$, $11,13]$.

Відтягнувши шлунок вниз та розсікаючи малий чепець, ми знаходимо першу непарну гілку черевної аорти - черевну артерію, яка, аналогічно черевному стовбуру аорти у людини [1, 10], відходить від вентральної поверхні аорти на рівні ніжок діафрагми. Вона має вигляд короткого стовбура, який поділяється на три артерії: ліву шлункову артерію, печінкову та селезінкову артерії.

Ділянки васкуляризації лівої шлункової артерії розповсюджуються на кардіальний відділ шлунка, малу кривизну, де вона утворює анастомоз з правою шлунковою артерією (від печінкової артерії).

Селезінкова артерія прямує вліво до селезінки позаду шлунка. Її добре видно після пересікання великого чепця та відведення шлунка вверх. За своїм ходом віддає чисельні гілки до тіла і хвоста підшлункової залози, великої кривини та дна шлунка.

Печінкова артерія після відгалуження від черевної артерії повертає вправо до печінки. На своєму початку віддає гілку, яка прямує до дванадцятипалої кишки і поділяється на праву шлункову та шлунково-дванадцятипалокишкову артерії. Про праву шлункову артерію ми згадували вище, вона замикає анастомоз разом $з$ лівою шлунковою артерією (від черевної артеріï) по малій кривині шлунка. Шлунково-дванадцятипалокишкова артерія своїми гілками розповсюджується на дванадцятипалу кишку, велику кривину шлунка, підшлункову залозу.

Найбільшою непарною гілкою черевного відділу аорти є верхня брижова артерія, яка міститься в товщі брижі тонкої кишки. Вона добре візуалізується після відведення поперечної ободової кишки вверх, а комплексу петель тонкої кишки - вліво. На своєму шляху вона перетинає спереду нижню порожнисту вену. Хід верхньої брижової артерії у білого щура супроводжується відгалуженням від неї цілого ряду гілок, а саме нижньої підшлунково-дванадцятипалокишкової артеpiï, яка васкуляризує головку підшлункової залози та ділянку верхнього згину дванадцятипалої кишки та численні порожньо-кишкові і клубовокишкові артерії, які кровопостачають однойменні відділи тонкої кишки. У ділянці клубово-сліпокишкового кута від верхньої брижової артерії відходить клубово-ободова артерія до кінцевого відділу клубової кишки, сліпої та початкового відділу ободової кишки. Кровопостачання висхідного відділу ободової кишки забезпечується правою ободовою артерією, а праві відділи поперечно-ободової кишки - середньою ободовою артерією. Остання утворює анастомоз у вигляді дуги 3 лівою ободовою артерією, яка є гілкою нижньої брижової артерії.

Відкинувши петлі тонкої кишки вверх i вправо, знаходимо нижню брижову артерію, яка $\epsilon$ непарною вісцеральною гілкою, що відходить від вентральної поверхні черевної аорти, поруч від місця початку загальних клубових артерій. Характерною особливістю анатомії товстої кишки білого щура є відсутність сигмоподібної ободової кишки, на відміну від людини. Низхідна ободова кишка продовжується у пряму кишку [6]. 3 огляду на це, ми спостерігали розгалуження нижньої брижової артерії лише на дві гілки: ліву ободову артерію та верхню прямокишкову. До лівого відділу поперечної ободової кишки та низхідної ободової кишки відходить вищезгадана ліва ободова артерія, яка разом 3 середньою ободовою артерією утворюють дугоподібний анастомоз. Безпосереднім продовженням нижньої брижової артерії $\epsilon$ верхня прямокишкова артерія, яка васкуляризує верхню третину прямої кишки.

Парні нутрощеві гілки черевної аорти у самців білого щура представлені лише двома гілками: нирковими та яєчковими артеріями. У відгалуженні ниркових артерій $є$ певні відмінності порівняно $з$ такими у людини [1]. Права ниркова артерія бере свій початок в грудному відділі аорти, вище місця відходження верхньої брижової артеpiï, перетинає ззаду нижню порожнисту вену i прямує дещо вище і позаду ниркової вени. Ліва ниркова артерія має типові відгалуження. Крім того, відомо, що третьою вісцеральною гілкою черевної аорти у людини є середня надниркова артерія $[1,9,13]$, яка у білого щура відсутня. У на- 
шому дослідженні виявилося, що обидві ниркові артерії дають початок нижнім наднирковим артеріям, причому справа у деяких експериментальних тварин разом $з$ нижньою наднирковою артерією відходила нижня діафрагмова артерія, що підтверджується даними літератури [6].

На невеликій відстані від місця початку i дещо нижче ниркових артерій відходить парна яєчкова артерія, причому права артерія починається трохи вище лівої. У деяких випадках яєчкові артерії відгалужуються від ниркових артерій [2, 5, 12]. Кожна 3 судин має косий низхідний напрямок, перетинає на своєму шляху вентральну поверхню сечоводів і проходить через пахвинний канал в калитку в складі сім'яного канатика.

Від задньо-нижньої поверхні кінцевого відділу черевної аорти білого щура, біля їі поділу на загальні клубові артерії відгалужується серединна хвостова артерія. Вона $є$ аналогом серединної крижової артерії у людини.

Кінцевими гілками черевної аорти є парна загальна клубова артерія. Біфуркація відбувається дещо нижче місця відходження нижньої брижової артерії. Вони йдуть латерально вздовж межі між поперековим та переднім хвостовим м'язами і по- діляються на зовнішню та внутрішню клубові артерії. Розгалуження загальної клубової артерії досить варіабельне. За літературними даними, поділ на зовнішню та внутрішню клубові артерії може взагалі не відбуватись, в такому випадку всі пристінкові та нутрощуві тазові гілки відходитимуть від загальної клубової артерії. В інших випадках, при наявності класичного поділу на зовнішню та внутрішню клубові артерії, стовбури їх будуть довшими, а кровопостачання стінок та органів таза буде здійснюватись гілками від внутрішньої клубової артерії [1]. У нашому досліді поділ загальної клубової артерії відбувався за традиційною схемою поділу на зовнішню та внутрішню клубові артерії, 3 подальшим розгалуженням на пристінкові та нутрощеві тазові гілки.

Висновок. У результаті проведеного нами дослідження встановлені особливості макроанатомії аорти білого щура, розгалуження їі на основні гілки та проведено порівняльну анатомію з аортою людини.

Перспективи подальших досліджень. Використовуючи білого щура для моделювання захворювань аорти, необхідно враховувати вказані вище особливості макроструктури аорти цієї експериментальної тварини.

\section{Список використаної літератури}

1. Околокулак Е.С. Проявления анатомической конституции в норме и при заболеваниях / Е.С. Околокулак, К.М. Ковалевич, Ю.М Киселевский. // Ж. Гродненского государственного мед. ун-та. - 2008. № 4(24). - С. 15-19. 2. Петренко В.М. Артериальный скелет тела человека / В.М. Петренко // Инновационная наука. - 2016. - № 2-5. - С. 125-127. 3. Петренко В.М. Морфотипь аорты и соматотипь человека / В.М. Петренко // Успехи современного естествознания. - 2015. - № 1-8. - C. 1282-1286. 4. Abramson D. Blood vessels and lymphatics in organ systems /D. Abramson. - Orlando (FL): Academic Press, 2012. - 792 p. 5. Anderson R.H. The surgical anatomy of the aortic root / R.H. Anderson // Heart. - 2000. Vol. 23. - Р. 670. 6. Ноздрачев А.Д. Анатомия крысы (Лабораторные животные) / А.Д. Ноздрачев, Е.Л. Поляков. - СПб.: Лань, 2001. -464 с. 7. Бураковский В.И. Хирургическое лечение врожденньх аномалий дуги аорты / В.И. Бураковский, Л.А. Бокерия, В.С. Аракелян // Материаль первого конгресса армянской ассоциации флебологов и ангиологов с международным участием. - Ереван, 2007. - С. 7-8. 8. Околокулак Е.С. Особенности строения дуги аорты и её ветвей / Е.С. Околокулак, Д.А. Волчкевич, Ф.Г. Гаджиева // Актуальные проблемы медицины: материаль ежегодной итоговой научной конференции (Гродно 15-16 декабря 2011 г.). - Гродно: ГрГМУ, 2011. - С. 429-431. 9. Быстрова М.М. Морфологические особенности строения верхнечелюстной артерии у взросльх людей / М.М. Быстрова // Укр. мед. альманах. - 2011. - Т. 14, № 2. - С. 27-29. 10. Бірюк І.Г. Вопросы развития сосудов брюшной аорты / І.Г. Бірюк, І.С. Герасимюк // Вісн. проблем біолог. і мед.. - 2010. - № 2. - С. 12-15. 11. Петренко В.М. Устройство организма у человека и высших животных / В.М. Петренко // Успехи современного естествознания. - 2014. - № 2. - C.32-35. 12. Settaci F. Anomalies and variant anatomy of the aorta and supraaortic vessels: additional challenges met by hybrid procedures / F. Settaci // HSR Proceedings in intensive care and cardiovascular anaesthesia. - 2008. - Vol. 18, № 1. - Р. 37-44. 13. Дуденко В.Г. Классификация артерий надпочечников человека / В.Г. Дуденко, А.А. Лермонтов // Морфология -медицинской науке и практике: сб. тр. науч.-практ. конф. с международным участием, посвященной 85-летию со дня рождения заслуженного деятеля науки Республики Беларусь, лауреата Государственной премии Республики Беларусь, профессора, доктора медицинских наук Петра Иосифовича Лобко (23-24 октября 2014 г.). - Минск, 2014. - С. 100-102. 
СРАВНИТЕЛЬНАЯ АНАТОМИЯ АОРТЫ И ЕЕ ВЕТВЕЙ

Резюме. Статья посвящена исследованию сравнительной макроанатомии аорты белой крысы. В работе представлены сведения, касающиеся организации отделов аорты, разветвления ее основных ветвей. Полученные результаты исследования могут быть полезными при моделировании заболеваний аорты, поскольку необходимо учитывать особенности макроструктуры аорты экспериментального животного для экстраполирования экспериментальных данных в медицинскую практику.

Ключевые слова: анатомия аорты, белая крыса.

\section{COMPERATIVE ANATOMY OF THE AORTA AND ITS BRANCHES}

Abstract. The article deals with the study of comparative macro anatomy of the aorta of white rat. The research represents data concerning organization of parts of the aorta and differentiation of its main branches. The results of research could be useful in modeling diseases of the aorta, because the peculiarities of macrostructure of the aorta of experimental animal are necessary to consider for introduction this information into medical practice.

Key words: anatomy of the aorta, white rat.

Danylo Halytsky Lviv National University (Lviv)

Надійшла 26.01.2017 p. Рецензент - проф. Слободян О.М. (Чернівці) 